UDC 811.111'25:622.276

DOI https://doi.org/10.32841/2409-1154.2021.48-4.22

\author{
Manhura S. I., \\ Lecturer at the Department of Germanic Philology and Translation \\ National University "Yuri Kondratyuk Poltava Polytechnic"
}

\author{
Palii K. V., \\ Ph.D., \\ Senior Lecturer at the Department of Germanic Philology and Translation \\ National University "Yuri Kondratyuk Poltava Polytechnic"
}

\author{
Mykhailova M. A., \\ Student at the Department of Germanic Philology and Translation \\ National University "Yuri Kondratyuk Poltava Polytechnic"
}

\title{
LINGUISTIC PROBLEMS OF TECHNICAL TEXT TRANSLATION (ON THE MATERIAL OF OIL AND GAS TERMINOLOGY)
}

Summary. Oil and gas industry is an international business and, accordingly, there is always a need for high-quality written translations of materials for successful cooperation and maintaining positions in the world market.

This leads to a constant demand for translations of various documents on oil and gas industry, including translation of tender documents, translation of drawings of oil and gas equipment, translation of documents for the development of oil and gas fields, translation of documents for the collection, transportation and storage of gas and oil, translation of documents on safety engineering. Especially often it is necessary to translate instructions for the operation of oil and gas equipment, which is mainly procurement and, as a result, due to the appearance of problems, requires more careful study during installation.

Thus, a detailed knowledge of not only a foreign language, but also the methods and principles of scientific-technical translation must be taken into account.

The article deals with peculiarities of translation of oil and gas terms. Attention is paid to the style and genre of the technical text. The main difficulties of the specific terminology translation are analyzed. The study conducted by the authors showed that the translation of oil and gas texts requires special narrowly focused training, in-depth knowledge of native and foreign languages. The paper considers examples of words and phrases that have the same meaning in the general language, but change it in a narrow sense, especially in combination with other words. This paper helps from the many meanings of any concept to find the closest to the main term of the target language equivalent in the original language.

Recently, terminological work is carried out on a large scale, but so far there are no exact answers to a number of key questions, especially the translation of terms is one of them. Taken it into account, the peculiarities of English terms translation of oil and gas industry are considered in the article. The paper presents the ratio of factors that determine the adequacy of the translation of oil and gas terminology from English into Ukrainian.

Key words: terminology, oil and gas industry, translator, language, translation, knowledge, features.

Formulation of the problem. The relevance is connected with an increasing number of new terms that were formed due to scientific and technological progress. It seems interesting to study the terminology in the oil and gas industry, as oil and gas are considered the main energy sources in the modern world and play an important role in trade relations between the states. This production sphere is developing dynamically, which mainly affects the livelihood of man. In addition, it should be mentioned that the study of oil and gas terminology expands the conceptual apparatus of this field of scientific knowledge.

Any professional translator is faced with the need to translate special terms from a particular area or type of activity. He has to solve the problem of understanding the meaning of such narrowly professional texts. In order to make a competent and most accurate translation it is necessary to know the basic specifics of terms translation. Scientific and technical texts reveal a number of grammatical, lexical and stylistic features that are particularly difficult for the translator, as these texts are purposed mainly for certain professional groups with specific extralinguistic knowledge, and therefore require particularly careful analysis. Many characteristics of scientific and technical style are present in both scientific and technical materials in Ukrainian and English.

Analysis of recent research. The problem of terminology translation remains especially relevant today in the scientific and technical boom and especially in the field of technical translation. Proper translation of technical terms is one of the most important aspects of any translation project. Modern companies working internationally understand that the consistency of terms underlies the understanding of meaning, and are seriously engaged in terminological work, clarifying the terms that can lead to misunderstandings. They develop special terminological databases that contain not only narrow-profile terminology specific to the industry, but also terminology that is not common [1].

One of the most difficult areas of technical translation is a specialized terminology in oil and gas. Oil and gas industry is important in Ukrainian economy. The translator of oil and gas technical texts requires an understanding of the terminology specifics of both English and Ukrainian versions. He must not only know both languages well, but also be well versed in the subject.

In addition, oil and gas sector combines a lot of technology from a variety of knowledge fields, such as engineering, chemistry, 
geology, insurance, accounting and others. The translator should be doubly attentive and never neglect the available reference materials $[2]$.

In general, both in English and in native languages, in all texts of this type, as indicated by V.N. Komissarov, there is a predominant use of scientific and technical terminology. V.N. Komissarov names the words and phrases denoting specific objects and concepts used by specialists in a particular field of science or technology [3].

A.A. Reformatsky defines the terms "as unambiguous words devoid of expressiveness" [4]. S.V. Grinev characterizes the term "as a special nominative lexical unit (word or phrase) of a special language, adopted for the exact name of special concepts", which are used by specialists in a particular field of science or technology [5].

During the rapid development of science, many terms began to penetrate into the general literary language and became known not even to specialists. As indicated by A.A. Miroshnichenko, they became to be called general scientific terms that are used in various fields of knowledge and belong to the scientific style of speech in general: experiment, adequate, equivalent, predict, hypothetical, progress, reaction, etc. [6].

The purpose of this paper is to highlight some aspects of the vocabulary functioning in the context of translation of oil and gas terminology and methods of terminology in this area, as well as to consider numerous examples of words that have one meaning in general but change it in a narrow sense, especially in combination with other words [7].

Presentation of the main material and substantiation of research results. To achieve adequacy in the translation of terms, it is important to understand the relationship between term and text, moreover, you need to understand the situation with the use of structural and semantic types of terms. It is also necessary to know the basic methods of translation [8]. Before starting to translate an oil and gas industry text, a translator must acquire the necessary knowledge about the oil and gas industry to more accurately find the equivalent in the language of translation, be able to choose the appropriate one for a given situation. It is very important to resort to translation transformations in the absence of an equivalent in the language of translation.

Thus, the translator of oil and gas industry needs a detailed knowledge not only of a foreign language, but also methods and principles of scientific and technical translation, and to be informed about the work of this industry [9].

Unfortunately, the equivalents of terms do not always exist, most often in the translation of terms use the following transformations:

- descriptive translation or explication - the most convenient way to explain an incomprehensible term, the only drawback cumbersome and verbose;

- transliteration - translation by reproducing a graphic form using the letters of the language of translation. But this is a rare case, this is how the translator's "false friends" appeared, such as contribution, data, decade, instance, simulation, etc., which grossly distort the content of the text;

- tracing - translation of terms by their exact reproduction by means of the Ukrainian language, or rather - literal translation.

Difficulties may arise with the translation of ordinary words, which in the end may turn out to be specialized terms.

We see a promising direction of research to further study the techniques and methods of translating technical texts and to identify ways to form new terms in the oil and gas industry. We emphasize that one term can be translated completely differently depending on the context, in our case - the industry. It is easy to guess how important the exact translation of technical terms is, especially when it comes to multimillion-dollar contracts [10].

Many elements of the rig and related objects have names associated with the names of animals, for example: doghouse, in this case we are not talking about a doghouse (as a non-professional translator could translate), but about the car of the driller; derrick man's working platform is called a monkey board, although the monkeys here, of course, don't make any sense. The term mousehole can also confuse an inexperienced translator [11].

Inaccuracies in the translation can lead to serious consequences: equipment damage, accidents, injuries at work. It is necessary to pay attention to ambiguity of terms [12].

We must also remember: before translating the text must be fully understood, aware of its content and essence. Initially, the translator is not a translator, he is only a reader who must understand the text as a native speaker, so he must have all the features of the language being studied (stylistics, vocabulary, grammar) and knowledge in this science [13].

At the same time, a number of features of oil and gas materials in the Ukrainian language are associated with specific structures of this language and stand out due to the peculiar use of such structures, in comparison with other styles of the Ukrainian language.

However, the main difficulties in translation are industry terms used in one field of knowledge, or narrow, specific to any area of a particular industry. For example, in the oil and gas industry they are: catchment, throttling, coke oven, swivel. In these private terminological systems the quintessence of each science, branch or kind of activity is concentrated.

The texts on oil and gas are one of the most difficult to translate in specialized vocabulary, as the terminology of the subtext of oil and gas production reflects the system of concepts used by its many industries. E.Sh. Dumitru in his dissertation points out that the core of this system is the terms of the thematic group "Drilling wells. Drilling equipment and technology", and the transition and peripheral areas of the system include terms of other sciences and branches of knowledge, which are an integral part of the terminology of oil production (so-called borrowed terms) [14].

During the formation of Ukrainian terminology of oil production there is a wide use of borrowed words. This phenomenon is characteristic for the terminologies of different languages and largely contributes to the internationalization of the languages of science.

Conclusions. The texts on oil and gas are one of the most difficult to translate in specialized vocabulary, as the terminology of the subtext of oil and gas production reflects the system of concepts used by its many industries. These examples show how important a high level of professionalism is for a technical translator, how important it is to study special literature and highquality, reference materials that are constantly updated to accurately translate technical terms from English.

Thus, when translating texts on oil and gas, the following difficulties may arise:

1. Ambiguity. Only with knowledge in the oil and gas industry, you can choose the desired translation of the term among many others.

2. Multicomponent. Each term can be either one-component or multi-component. When working with the text it is necessary to 
check the translation of the concept separately and in combination with the neighboring word.

3. Ignorance of terminology in the Ukrainian language. The translator can find a suitable translation of the term into Ukrainian, but will not know its exact meaning. In such situations, knowledge in the oil and gas industry will also be needed.

4. Realities. The names and their translations must be checked, as they often already have their own translation in different languages.

The difficulties of translating terms mentioned in the article, explaining how to overcome them, should help the translator to achieve accuracy, adequacy of translation, to minimize errors. For these purposes it is also necessary to pay attention to the main methods of translation, to know the specifics of the industry. In general, the oil and gas sector combines a lot of technologies from different fields of knowledge, such as engineering, chemistry, geology, insurance, accounting and others. You also need to know this terminology. Moreover, with the development of new technologies, equipment, areas of activity, oil and gas companies often develop their own terminology, which also needs to have an idea.

\section{References:}

1. Карабан B.I. Переклад англійської наукової і технічної літератури : посібник. Вінниця : Нова книга, 2002. 564 с.

2. Комиссаров В.Н. Теория перевода (лингвистические аспекты) : учебник. Москва : Высшая школа, 1990. 253 с.

3. Каткова С.В. Формирование навыков самостоятельной работы студентов при обучении профессионально-ориентированному иностранному языку в вузе. Молодежь и наука : сборник материалов VIII Всероссийской научно-технической конференции, посвященной 155 -летию со дня рождения К.Э. Циолковского. г. Красноярск, 19-27 апреля 2012 г. Красноярск, 2012. С. 187-190.

4. Реформатский А.А. Введение в языковедение : учебник. Москва : Аспект-Пресс, 2001. 536 с.

5. Гринев-Гриневич С.В. Терминоведение : учебное пособие. Москва : Издательский центр «Академия», 2008. 307 с.

6. Мирошниченко А.А. Деловое общение : учебно-методический комплекс. Москва : МИЭМП, 2008. 86 с.

7. Мангура С.І. Деякі особливості перекладу англомовної нафтогазової термінології українською мовою. Інноваційні технології у контексті іншомовної підготовки фахівия : матеріали II Всеукраїнської науково-практичної інтернет-конференції, м. Полтава, 2 квітня 2015 р. Полтава, 2015. С. 95-98.

8. Сухенко К.М. Лексичні проблеми перекладу : посібник. Київ : Вид-во Київського університету, 2000. 124 с.

9. Ефремов А.А. Когнитивные и структурно-семантические особенности метафорических терминов (на материале терминологии американской нефтегазовой отрасли) : автореф. дисс. ... канд. филол. наук. Майкоп, 2013. 28 с.

10. Бреус Е.В. Основы теории и практики перевода с русского языка на английский : учебное пособие. Москва : УРАО, 2004. 208 с.

11. Хатруков Е.М. Англо-русский словарь по нефтяному бизнесу. Москва : Олимп-Бизнес, 2008. 400 с.
12. Каткова С.В. Мультимедийные программы обучения иностранным языкам в высшей школе. Вестник КИГИТ. 2006. № 1. С. 125-128.

13. Татаринов В.А. Теория терминоведения : учебник : в 3 т. Москва : Московский лицей, 2000. Т. 1 : Теория термина: история и современное состояние. $311 \mathrm{c}$.

14. Думитру Е.Ш. Структурно-семантический анализ русской терминологии нефтедобычи : дисс. ... канд. филол. наук. Москва, 2003. $120 \mathrm{c}$.

Мангура С. І., Палій К. В., Михайлова М. А. Лінгвістичні проблеми технічного перекладу (на матеріалі нафтогазової термінології)

Анотація. Нафтогазова галузь - це міжнародний бізнес, а отже, його учасникам завжди потрібні якісні письмові переклади матеріалів на цю тему для успішної співпраці та збереження своїх позицій на світовому ринку. Це приводить до постійного попиту на переклади різноманітних документів iз нафтогазової сфери, зокрема переклади тендерних документів, креслень нафтогазового обладнання, документів на розробку нафтових і газових родовищ, документів на збір, транспортування та зберігання газу й нафти, документів із техніки безпеки. Особливо часто доводиться перекладати інструкції з експлуатації нафтогазового обладнання, яке $є$ здебільшого закупівельним, а тому, з огляду на появу проблем, виникає необхідність більш ретельного його вивчення під час монтажу.

Таким чином, необхідне детальне знання не лише іноземної мови, а й методів та принципів технічного перекладу, а також повне усвідомлення роботи цієї галузі виробництва, адже перекладач повинен розуміти контекст, щоб правильно перекласти текст.

У роботі виявлено співвідношення факторів, що визначають адекватність перекладу нафтогазової лексики з англійської мови українською мовою. У статті розглядаються особливості перекладу нафтогазових термінів. Звертається увага на стиль i жанр технічного тексту. Проаналізовано основні труднощі перекладу зазначеної термінології. Дослідження, проведене авторами, показало, що переклад нафтогазових текстів вимагає спеціальної вузькоорієнтованої підготовки, глибоких знань рідної та іноземних мов. У статті розглядаються приклади слів i фраз, що мають однакове значення в загальній мові, проте змінюють його у вузькому розумінні, особливо в поєднанні 3 іншими словами. Розглянуто особливості перекладу англійською мовою текстів нафтогазової галузі.

Отже, у дослідженні представлений алгоритм перекладу спеціальної лексики в оригінальних нафтогазових текстах, у текстах, пов'язаних із нафтогазовою термінологією, з метою підвищення ефективності прийняття рішень та адекватності перекладу.

Ключові слова: термінологія, нафтогазова промисловість, перекладач, мова, переклад, знання, особливості. 